\title{
Corrigendum
}

\section{Was Martha of Bethany Added to the Fourth Gospel in the Second Century?-CORRIGENDUM}

\section{Elizabeth Schrader}

DOI: https://doi.org/10.1017/S0017816016000213, published online by Cambridge University Press, 8 September 2016

There are two errors in footnote 1 of the article by Elizabeth Schrader, published online on 8 September 2016 and also appearing in print in this issue of Harvard Theological Review. ${ }^{1}$ The listed link for "An Electronic Edition of the Gospel according to John in the Byzantine Tradition" (http://www.iohannes .com/byzantine/ $\mathrm{XML} /$ transcriptions) should be http://www.iohannes.com/byzantine/XML/start. xml. However, this correct link has been incorrectly attributed to "Vetus Latina Iohannes: The Verbum Project." The link for the Vetus Latina manuscripts should be http://www.iohannes.com/vetuslatina/edition/index.html. The footnote in full should read as follows:

These include the following: the International Greek New Testament Project [IGNTP] (University of Birmingham), "IGNTP Transcripts: A Transcription of John in P66," Electronic Editions of the Gospel according to John in Greek, Latin, Syriac and Coptic, 17 December 2009, http://www.iohannes.com/XML/ transcriptions/greek/04_P66.xml; the United Bible Societies, "An Electronic Edition

${ }^{1}$ Elizabeth Schrader, "Was Martha of Bethany Added to the Fourth Gospel in the Second Century?," HTR 110 (2017) 360-392, at 360-61. DOI: https://doi.org/10.1017/S0017816016000213 
of the Gospel according to John in the Byzantine Tradition: The Byzantine Edition of John; Transcriptions" (ed. Roderic L. Mullen with Simon Crisp and David C. Parker; 2nd ed.), Electronic Editions of the Gospel according to John in Greek, Latin, Syriac and Coptic, August 2007, rev. July 2014, http://www.iohannes.com/ byzantine/XML/start.xml; Vetus Latina Iohannes: The Verbum Project, "The Old Latin Manuscripts of John's Gospel” (ed. P. H. Burton et al.), Electronic Editions of the Gospel according to John in Greek, Latin, Syriac and Coptic, September 2007, rev. April 2015, http://www.iohannes.com/vetuslatina/edition/index.html; Ulrich B. Schmid, W. J. Elliott, and David C. Parker, The Majuscules (vol. 2 of The New Testament in Greek IV: The Gospel according to St. John; NTTS 37; Leiden: Brill, 2007); Reuben Swanson, New Testament Greek Manuscripts: Variant Readings Arranged in Horizontal Lines against Codex Vaticanus (Sheffield: Sheffield Academic, 1995); and the University of Münster, Institut für Neutestamentliche Textforschung [INTF], New Testament Transcripts Prototype, http://nttranscripts. uni-muenster.de/AnaServer?NTtranscripts+0+start.anv. Editions by Tischendorf, von Soden, Wettstein, and Wordsworth and White have also been consulted; see Novum Testamentum Graece (ed. Constantinus Tischendorf; Leipzig: Tauchnitz, 1862); Die Schriften des Neuen Testaments in ihrer ältesten erreichbaren Textgestalt auf Grund ihrer Textgeschichte (ed. Hermann Freiherr von Soden; 2 vols.; Göttingen: Vandenhoeck \& Ruprecht, 1911-1913); Novum Testamentum Graecum (ed. Jacobus Wettstein; Graz: Akademische Druck, 1962); and Nouum Testamentum Domini Nostri Iesu Christi Latine. Secundum Editionem Sancti Hieronymi (ed. John Wordsworth and Henry Julian White; Oxford: Clarendon, 1889-1954). 